$$
\text { 古バビロニアの abbuttum について }
$$

黒田和彦

1.

シュメール語音とアッカド語音とを記した $\mathrm{S}^{\mathrm{b}}$ vocabulary ール語の qa-ar という音価はアッカド語の ab-bu-ut-tum という音価 に相当することが記されている。すでに Uruk 第 IV 層から GÀR (=qar) の文字が出現していることは Falkenstein によって明らかにされ 售(3)また GÀR の文字は Deimel によって招介された Fara出土のタブ レットの中にも記されていることが知られている。

GÀR という文字は Urukagina の時代, アッカド王朝時代の史料の 中にもしばしば現れるが，長さの単位を意味していたらしい。しかしウ ル第三王朝時代以後 GÀR=abbuttum とされるようになったのである。 abbuttum は一般に奴隷のしるしであるとされ，いわゆるシュメール 親族法 1 条，エシュヌンナの法典 51-52 条， 八ムラビ法典 146 条， 226-227 条及び古バビロニア時代の契約書などに記載されている。

本稿では古バビロニア時代の abbuttum がいかなるものであったか， またどのような目的のもとに法文化されたかなどについて論じてみた い。

\title{
2.
}

1）シュメール親族法 1 条

シュメールの法律文言集であり，アッカド語の対訳がつけられている ana ittiš の 7 表 III 欄 23-28 行には

もし息子が被の父に「あなたは私の父ではない。」というならば, 
彼を剃り (ú-g[al-la]-ab-šu)，彼に abbuttum をつけ（ab-bu-[ut]-tum i-ša-ak-kán-šú)，そして彼を銀のために与兄る（六 a-na KÙ. BABBAR i-nam-din-šú)。（）中の翻字纯ッカド語の部分

と記されている。

この条文は養子が養父にそむき，親子関係の否認を宣言することに対 する法律的な制裁について規定している。また養母に向って同様の非行 を犯した湌子に対しては 31-33 望に

彼の muttatum 剃り (mu-ut-ta-as-su ú-gal-bu-ma), 彼を町中に引き まわし，そして家から追い出す。 と規定している。

養子が養父に反抗した場合の罰則は

(1) 彼を剃る。

(2) 彼に abbuttum をつける。(abbuttam šakânu)

(3) 銀のために彼を与える。すなわち奴隷として買却する。 の三段階に分けて記されている。剃るというのは養母に反抗した場合の 罰則 muttatum を剃る（muttatam gullubu）に相当すると思われる。 Szlechter によれば, muttatum は“partie antérieure”辛(9) であり，頭の前 部を意味する。 muttatum を苟るとは前頭部の髮を剃る事であるのがわ かる。

一般に古代セム民族の間では自由人の象徵としての前頭部の髮の存在 を重要視したといわれている。前頭部の髪を剃られることは自由の衰失 を意味し，法律的な資格を迫奪されることではあったが，乙かし前髪を 剃られること自体が奴隷にされるということを意味したのではなかっ た。養父に反抗した養子は自由人としての名誉をまずきずつけ售(11) いで奴隷の目印である abbuttumをつけられて，奴隷として買却される のである。

エシュヌンナの法典, ハムラビ法典には同様の条文は存在しない。し 
かしバビロソ第一王朝時代のバビロニアにはシュメール親族法 1-2 条の 条文を裏付ける慣習法が存在していた。その事を実証するのはバビロン 第一王朝時代の養子契約について記した私文書である。M 97 には「銀 のために彼を与える。よあり，また M 96 には「彼に abbuttum をつ け，銀のために彼を与える。と記されている。 M 95 には「彼を剃り， 彼に abbuttumをつけ，銀のために彼を与える。とあり，まさにシュ メール親族法第 1 条の罰則に相当するのである。

シュメール親族法に記載されているように abbuttum をつけることは 自由人を奴隷化するための一つの法手続であることがわかるのである。 2) エシュヌンナの法典 $51-52$ 集(15)

kanum, maškanum 及び abbuttum をつけたところの（ša ka-an-nam maš-ka-nam ù ab-bu-ut-tam ša-ak-nu) エシュヌンナの男奴隷 または女 奴隷はその所有者の許可なしにェシュヌンナの門を離れてはいけな い。 51 条

外国の使臣の保護のもとにエシュヌンナの門に入った男奴隷または 女奴隷は, kanum, maškanum 及び abbuttumをつけられなければ ならないが (ka-an-nam maš-ka-nam ù ab-bu-tam iš-ša-ka-an-ma), しか しその主人の保護下にとどまる。52 条（）中はタブレットAの暗字 エシュヌンナの法典によっても奴隷は abbuttum をつけられていたこ とがわかる。Goetze は kanumは奴隷の首のまわりに結びつけられた紐， maškanum は鎖であるとしている。 䛨(15) をつけられていたのである。 51 条はエシェヌンナの奴隷が他国へ逃亡 する事を禁止した規定であり，当時の小国家であるエシュヌンナの奴隷 所有者の所有権を保護する意図のものであろう。52 条は外国の使臣が 所有している奴隷にもエシュヌンナの国法に従って kanum, maškanum 及び abbuttumをつけなければならないということが記され，乙かし外 国の使臣の奴隷所有権は侵されないことが明記されている。 
この条文をみるとエシュヌンナの国に拈いては国法により奴隷身分を 明確にするために，奴隷のしるしをつける事を強制したように感じられ るかも知れない。しかし当時の政治状勢を考察する時簡単にはそらいえ ないのである。何故なら当時はいわゆる Zweite Zwichenzeit の頃であ り, イシン, ラルサ, エシュヌンナ等の抗争がはげしく, その様な争乱 にうち勝つためには自国内を固める必要があった。そのため国内の奴隷 所有者の所有権を保護しなければならなかったのであろう。

3) ハムラビ法典 146 望(18)

もし人が nadîtum をめとり，そして彼女が夫に女奴隷を与え，そ の女奴隷が息子達を生み，その後にその女奴隷が彼女の女主人と同 等の地位にたとうとするならば，彼女が彼女の女主人のために息子 を生んだが故に，彼女の女主人は彼女を銀のために与えてはならな い。abbuttum を彼女につけ (ab-bu-ut-tam i-ša-ak-ka-an-ši-ma), 女奴 隷として彼女を算入する。

女祭司 nadîtum に子供が生まれない場合，彼女は夫に女奴隷を妾と して与えることにより離別からまぬかれた。その女奴隷は夫に対しては 妾であるが, nadîtum の召使であるという関係は失われない。女奴隷が 息子を生みその後に正妻である nadîtum と同等の地位を要求した場合, 罰として彼女は abbuttumをつけられ，妾の地位から追放され，もとの 女奴隷という身分におとされるのである。ここで注意すべきは abbuttumをつけられて女奴隷の一人として算入されるが，買却されないとい うことである。しかし 147 条では女奴隷に子供がなければ奴隷として買 却されると規定している。つまりシュメール親族法の罰則の順序と同様 の順序がうかがえるのである。さらにこの女奴隷は妾となった際に， abbuttumをとりはずされ，女主人に反抗した時にはまた再び abbuttum をつけられるのであり，abbuttum は容易につけたり，なくしたりする ことが可能であることを示している点に注意しなければならない。 
abbuttum について（黒田）

4) ハムラビ法典 226-227 条

も乙理髪師が奴隷の主人の 意志なしに，自分の所有でない奴隷の abbuttum を剃り落した（ab-bu-ti ERU(M) la še-e-im ú-gal-li-ib）ときは その理髮師の手を切り取る。226 条

もし人が 理髪師をあざさいて, 理髪師が自分の所有でない奴隷の abbuttum を剃り落した（ab-bu-ti ERU(M) la še-e-im ug-tá-al-li-ib)-と さは，その人を殺し，彼の門に彼をつるし，理髪師は「知って剃り 落したのではありません。と誓って自由となる。 227 条

226-227 条から一般に奴隷には abbuttum がつけられていたこと がわかる。理髪師はシュメール語で ŠU.I, アッカド語で gallabum と 記され, 字義通りに解釈すれば床屋である。浬髪師が奴隷の主人の意志 に反して abbuttum を苟り落した場合の罰として手を切断されるのであ る。またもし人にあざむかれて他人の奴隷の abbuttum を剃り落した時 は，知らないで剃り落したと誓って無罪となるが，しかしあざむいて他 人の奴隷の abbuttum を剃り落させたものは死刑となり，かつまた彼の 門にさらされるのである。

abbuttum がどのような目印であったかについていろいろな論争がな されて水り，これに関して gallabum, gullubu という言葉が重要な鍵と なっている。これについては後述する。

何故この様な条文が存在するのかということについては次のような解 釈が可能であろう。ハムラビ法典は自由人（awîlum）の所有権を極めて 厚く保護して拈り，所有権を侵す者に対しては重罪をもってこれに当っ たのである。例えば 15 条では奴隷を逃亡させた者に対しては死刑を課 すべさことが規定されている。また 7 条では梁約書なしに. 物品（奴隷も 含む）を購入し又は寄託を受けた時は死刑に処せられるのである。奴隷 はもとより奴隷の主の所有物であり， abbuttum を悌り落すことは所有 権を侵害することであった。abbuttum のない奴隷は逃亡しやすく，ま 
た奴隷自身が好む新しい主人の下に逃亡する危険をはらんでいた。それ 故 abbuttumを剃り落すことは所有権に対する重大な脅威であったから この様なことが規定されたのであろう。

Ammiditana 代の奴隷解放文意の中には abbuttum を剃り落すことが 記されている。これには Warad-bunene という男が Tupliaš という土 地へ奴隷として買却されたが，5年の労働の後バビロンに逃げ帰り，バ ピロンの 2 人の長老 (abi sâbêtmes) のもとに扔もむき，ハムラビ法典 (註27)

280 条に従って奴隷身分からの解放を宣言してもらったことが書かれて いる。12-13 行には「汝は自由である (el-li-ta)。汝の abbuttumは剃り 落される（ab-bu-ut-ta-ka gu-ul-lu-ba-at）。」ある。すなわち奴隷解放のた めの法的手続として abbuttumを剃り落さなければならないのであった。

3.

以上が奴隷のしるしとしての abbuttum について記載した史料である がその他にも abbuttum について記した史料は少なくない。ここではそ れらの史料について触れながら abbuttum が何であったかについて述べ てみよう。

シュメール語の GÀR の Urbild は Deimel によればいっぱいにみた されたそしてロをしめられた袋（または束ねられた䫓㰮）であったと推定 されている。しかし実際には GÀR の本来の意味は不明である。エシュ ヌンナの法典やハムラビ法典の abbuttum は一体何であったろうか。古 バビロニア時代の abbuttum は奴隷の目印であったには相違ないが，乙 かしどのような目印であったろうか。

abbuttum について多くのアッシリア学者, 古代法制史家の見解が提 出されている。先ず第一に Delitzsch, Walter, Koschaker, Goetze など の学者は abbuttum を Fessel（鎖）と関連させて考えている。その根拠 となるのはあるタブレッ゙ッ erimaškanum, erizuqaqînum とならんで 
erìabbuttum と記されているからである。何故なら erî は青銅製品を示 す決定詞であり，zuqaqîpum は蛇を示す言葉だからである。Goetze は Koschaker の説を支持し， abbuttum は奴隷をつなぐ鎖に結びつけられ た環または札であるとしている。

しかし他のタブレットには UZUGÀR= 註(34) 身体の部分を示す言葉であることが解ると共に Fessel 説に対する訂正 が行なわれるようになった。

第二は頭髪と関連させる考え方である。Landsberger は abbuttum は 本来は Fessel であったが後に特別な髪形 (Haartracht) に変ったのだと した。Dhorme は奴隷の象徵をかたどる鎖の形をした組髪であると考え た。また Thureau-Dangin は苟髪のようなものであろうと推定じた。 カゴ大学のオリエント研究所のアッシリア語辞典は abbuttu-lock, Soden のアッカド語中辞典は Haartracht としている。

第三の説は Szlechter, Driver-Miles などの入墨説である。Szlechter は あご,歯ぐき,胆汁の次に UZU・GÀR が記載されていることから UZU・ GÀR を入墨のために生じた傷と翻訳し， erìabbuttum を入墨を入れる ための道具であると考えた。

第四の説は単に奴隷の目印とするだけでそれが何であるかを示さない 註(41) 註(42) 註(43)

Scheil, Eilers, Pohl-Follet などの説である。

シュメール親族法 1 条，エシュヌンナの法典 51-52 条，ハムラビ法典 146 条には abbutum šakânu と記されているが, šakânu は「おく」と か「つける」とか「作る」というょうな意味であり，この動詞からは abbuttum の性格を断定することは不可能である。

しかしハムラビ法典 226-227 条には abbutam gullubu と書かれてお り，扮执よその見当はつけら机るのである。Goetze は gullubuを剃り 落すとせずに clean away (取り去る) と翻訳している。Szlechter は八ム ラビ法典 226-227 条の gallabum は外科医を兼㸚た理髪師であったろう 
と考え gallabum が入墨を消すのであるとした。Driver-Miles も同様の

見解を発表した。しかし gullubu は剃るという意味であり，入墨を軽い 手術によって消すのではないと考学られる。ここでは単純に理髪師が剃 り落すことの出来るものを abbuttum と呼ぶべきであると思う。エシュ ヌンナの法典の奴隷につけらるべき kanum, maškanum, abbuttum は 容易につけることができるものであることを暗示している。 ellata abbuttaka gullubat という奴隷解放の手続が手術によってではなく，理髪 師によって簡単に行なわれたのではないだろらか。というのはハムラビ

法典 117 条には自由人の妻子が売却された場合 4 年目には解放が行なわ るべさことが記されている。このように 3 年たった後の自由が保障され ている者にど5して入墨を施す必要があったろうか。

さらに abbuttum=入墨説に対するもら一つの反証がある。ハムラビ 註 (49)

法典 265 条の家畜の目印は šimtum とい5名称で呼ばれている。 šimtum は入墨または焼印であったと考光られる。奴隷の目印が入墨や焼印であ るならば abbuttum とは呼ばれずに šimtum と呼ばれたはずである。 新バビロニア時代にも abbuttum から解放されるという語句がある。一 方家畜の目印である šindu=šimtum が奴隷の片方または両方の手首に 施され，現在または将来の所有者の名前が書かれていたさ售(51) る。このように入墨をたは焼印に当る語は Simtum と呼ばれ，abbuttum ではなかったことがわかるのである。

つまり abbuttum は頭髮に施した目印であったと推定されるのであ る。eriabbuttum はそのような頭髮を結ぶ金属性の帯であるかも知孔な い。新バビロニア時代のタブレットにはURUDabbuttu=birītu(鎖) と記 されていて，このような考え方に証拠を提供するのである。UZU GÀR のような身体の部分を示すしいて結びついた abbuttum はあざまたは 傷の形が abbuttum の形をしていたために用いられたのであろう。なお バビロン第一王朝とほぼ同時代の Alalakh, 中アッシシリア, Nuzi, 新バ 
ビロニアでも abbuttum なる語が使われていたことは史料により明らか である。

先に述べたように古バビロニアの abbuttumは奴隷の目印であり，そ れは頭髮の特殊な結い方によって示された。奴隷はセム民族が最も重要 視する前頭部の髪の毛を剃られ，しかも後髮部に abbuttumをつけられ て自由人と区別された。それ故 abbuttum はまず自由人と奴隷とを区別 する標識であった。更にそれ以上に奴隷の主の所有権を確認するための 目印でもあっだ。古バビロニアの奴隷の持主は特殊な例を除いてせいぜ い1-2 人の奴隷しか保有していなかったし, バビロニアの農業は小規模 な家内労働によって支えられていたとされている。奴隷の価格は普通銀 1/3 マナであり, 極めて高価であった。しかもこのような奴隷は家事に 従事していたらしい。このような理由から奴隷の所有者にとって奴隷に 逃亡されたり，死亡されたりすることは重大な損失で岕った。こうした 奴隷所有者の所有権を確認することが国家にとってぜひとも必要とされ たのであろう。かつまた奴隷の身分は固定的なものではなかったことに 注意しなければならない。奴隷解放の機会は相当あったし，自由人は負 債のために妻子を奴隷化することもあった。それ註(57) abbuttum は容易に つけられまた簡単に剃り落される性格のものであったと思われる。さら にウル第三王朝時代以降 GÀR=abbuttum という語が用いられるように なったことは注目に洒する。浮彫, 彫刻, その他の芸術作品からみる限 り, シュメール人の間では神官や lugal, ensi 等の支配階層は剃髮して いたのであり，七ム民族の自由人の象徴としての前頭部の毛髪について は全然気にとめていなかったのである。

恐らく，元来 abbuttum はセム民族の奴隷の目印であったが，次第に シュメールの法慣習の中に侵透していったのであろう。ウル第三王朝時 代にはすでに GÀR=abbuttum という対訳が出来, セム民族の国家で あるエシュヌンナやバビロン第一王朝の時代には遂に法典に記載される 
ようになったのである。むた私的経済が発達しつつあるウル第三王朝時 代に abbuttum という語が出現していることは興味深いことである。

註

(1) abbuttum について論じた文献は多いが，次の四つの文献が最も重要である。 P. Koschaker; Rechtsvergleichende Studien zur Gesetzgebung Hammurapis König von Babylon. Leipzig. (1917) S. 202-204, 236.

M. David; Die Adoption im altbabylonischen Recht. Leipzig. (1927) S. 48 -52 .

F. R. Kraus: Orientalia 16 (1947) p. 180-184.

E. Szlechter; Essai d'explication des clauses muttatam gullubu, abbuttam sakanu et abbuttam gullubu. Archiv Orientální XVII (1949) p. 391-418.

(2) B. Landsberger. u. a.; Matelialien zum Sumerischen Lexikon. III. Rom (1955) S. 143. S ${ }^{b}$ A Z. 193.

(3) A. Falkenstein; Archaische Texte aus Uruk. Berlin (1936) S. 97-98.

(4) A. Deimel; Die Inschriften von Fara I. Liste der archaischen Keilschriftzeichen von Fara. (WVDOG40) Leipzig (1922) S. 19.

(5) Szlechter; Ibid. p. 403.

（6）新バビロニア時代には abbuttumは「奴隷のしるし」以外の意味にも用いら れた。しかし本稿てはこれに関しては省くことにする。

W. Soden; Akkadisches Handwörterbuch. Lieferung I. Wiesbaden (1959)

S. 5-6 参照。

(7) B. Landsberger; MSL I Roma (1937) S. 101.

(8) Landsberger; a. a. O., S. 102.

(9) Szlechter; Ibid., p. 397-398.

(10) B. Meissner; Babylonien und Assyrien I. Heidelberg (1920) S. 410-411.

(11) Koschaker: a. a. O., S. 204-210 参照,

前頭部の髮を剃ることは Ehrenstrafe であるとしている。（S. 208）

(12) J. Kohler, A. Ungnad; Hammurabi's Gesetz III. Leipzig (1909) Nr. 23.

(13) HG III Nr. 22.

(14) HG III Nr. 19.

(15) A. Goetze: The Laws of Eshnunna. (AASOR 31) New Haven (1956) pp. 125-6.

51 条はタブレット A （IM 51059）Col. 4 11. 7-9. 及び B (IM 52614） Col. 4, 11. 11-13.

52 条は A. Col. 4 1l. 10-13 及び B. Col. 4 11. 14-16.

(16) Ibid., pp. 128-9. 
abbuttum について（黒田）

Böhl は k.m.a. を各々 band, boei, slavenmerk としている。

L. Böhl; Het akkadische Wetboek van Bilalama, Koning van Esjnunna. JEOL 11 (1949-50) p. 104-105.

(17) D. O. Edzard; Die zweite Zwischenzeit Babyloniens. Wiesbaden (1957).

(18) CH. Col. viii b $11.43-59$.

(19) G. R. Driver and John C. Miles; The Babylonian Laws I. Oxford (1956) 2nd Edition. pp. 305-6.

(20) $\mathrm{CH}$ Col. viii b. 11. 60-64.

(21) 226 条 $\mathrm{CH}$ Col. xix b ll. 36-42. 227条 $\mathrm{CH}$ Col. xix b 11. 43-55.

(22) J. Gelb and others; The Assyrian Dictionary of the Oriental Institut of the University of Chicago Vol. 5. Chicago (1956) pp. 14-17.

(23) Driver-Miles; Ibid., pp. 421-425.

(24) $\mathrm{CH}$ Col. viii a ll. 30-36.

(25) $\mathrm{CH}$ Col. vi a 1l. 41-55.

(26) CT $29 \mathrm{Bu} 91-5-9,419$.

M. Shorr; Urkunden des altbabylonischen Zivil-und Prozessrechts. Leipzig (1913) Nr. 37 に翻字, 翻訳がある。

(27) $\mathrm{CH}$ Col. xxiii b, 11. 72-87.

(28) A. Deimel: Šumerische Lexikon. Heft 11. Roma (1930) S. 597.

(29) F. Delitzsch; Sumerische Glossar. Leipzig (1914) S. 82.

(30) A. Walter; Das altbabylonische Gerichtswesen. Leipzig (1917) S. 236-237.

(31) Koschaker; a. a. O., S. 203.

(32) Goetze; Ibid., p. 128.

(33) VR 27 1. 38.

(34) UMBS XII-1, No. 7, Col. 1.

(35) B. Landsberger; Der Kultische Kalender der Babylonier und Assyrier.

Leipzig (1915) S. 115. JCS 4 (1950) p. 8 参照,

(36) Szlechter, Ibid., p. 404.

(37) Gelb; Ibid., pp. 14-15, 130.

(38) Soden; a. a. O., S. 5-6.

(39) Szlechter; Ibid., p. 406.

(40) Driver-Miles; Ibid., pp. 306-309.

(41) V. Scheil; La loi de Hammurabi. Paris (1904) p. 28, 45-46.

(42) W. Eilers; Die Gesetze Chammurapis (AO 31 3/4) Leipzig (1932) S. 36, 48, 79.

(43) A. Pohl et R. Follet; Codex Hammurabi. Transcriptio et versio Latina. Roma (1950) p. 33, 46. 
(44) Deimel; ŠL. Šumerisch-Akkadisches Glossar. Rom (1925-1934) S. 422.

(45) Goetze; Ibid., p. 128.

(46) Szlechter; Ibid., p. 412-418.

(47) Driver-Miles; Ibid., p. 422

(48) $\mathrm{CH}$ Col. iii b. 11. 54-67.

(49) CH Col. xxii b ll. 82-89.

(50) S. Langdon; Babylonian wisdom. Babyloniaca VII (1930) pp 129-229. 中 の p. 188.

(51) M. San Nicolò und A. Ungnad; Neubabylonische Rechts-und Verwaltungsurkunden I. Leipzig (1935) Nr. 85, 90.

(52) CT 14840.

(53) Gelb; Ibid., p. 130.

(54) Driver-Miles; Ibid., p. 307.

R. Labat; Hémélologies et ménologie d’Assur p. 126-7 K abbuttum が記載 されているといわれるが筆者末見。

(55) E. Chiera; Excavations at Nuzi I. Cambridge U.S.A. (1929) H 73. 翻字 翻訳は E. A. Speiser; New Kirkuk documents relating to Family Laws AASOR X (1930) pp. 1-76. 中の No. 20（H 73）にある。このタブレット は Akkuya の子 Zigi が彼の息子達と彼の妻 Zilipkiashe を受益者として財産 譲渡を行うことを記した私文書である。Zilipkiasheに分割された財産は彼女の 死後各自の取分に従って息子達に再分割される。しかし息子達は母に従わなけ ればならない義務を負っているのである。父の死後母の云いつけに従わない息 子達に対して 22-23 行には「彼等に abbuttum を固着し，そしてそれを彼等の 足に就く」(ab-bu-ta-šu-nu ú-maš-šar-šu [ù] i-na šēpi-šu-nu i-na-an-di-nu)。と 記されている。これをみると abbuttum は頭髪とは関係がないことは明らかで 女る。Driver-Miles は固着ではなく深く切り込むと翻訳し， abbuttumは入墨で あるとした。しかしこの場合の abbuttum は一種の木札または粘土の下げ札の ようなもので,それを足に結びつけていたと考える方が妥当であろう。何故なら 母に反抗してこの様な罚を受けても，親子であるという法的関係には変更がな いと次の 24-25 行に記されているからである。ヌジの abbuttum はどの様な解 釉を行っても古バビロニアのそれとは異っており，このことはむしろバビロニ アとヌジの法習慣の相違を示するのであると考党た方がよいのではあるまいか。

(56) I. Mendelsohn; Slavery in the Ancient Near East. New York (1949) pp. 117-120.

(57) Alalakh 王 Niqmepa と Tunip 王 Ir-MI との間に結ばれた条約文の中には, 逃亡奴隷引渡しのための条項が記載されている。I. Mendelsohn; On Slavery in Alalakh. Israel Exploration Journal V (1955) pp 65-72. 参照.

(58) Driver-Miles; ibid., p. 222. 


\section{Chaos in the Hebrew Creation Myth}

\section{Susumu JozAKI}

Regarding the nature of chaos in the Hebrew Creation Story in the Book of Genesis, after a syntactical survey of the text and an examination of the usage in the O.T. of the words signifying chaos, this reporter has reached conclusions as follow:

A. Chaos is a state before the creation and is not the product of the creation by God.

B. Chaos here signifled by tōhû, bōhù, tehòm, and máyim is rather a symbol of non-existence, and is not material of creation.

C. But the text does not concern the theme of creatio ex nihilo but unreality, insecurity, meaninglessness of the world without God.

D. This creation story tells the overcoming by God of such unreality and insecurity, and enduing with reality.

E. This creation story is a confession of Hebrew faith in God through a myth rather than a cosmogony as such

\section{abbuttum in Old-Babylonian Period}

\section{Kazuhiko KURodA}

$G \grave{A} R=a b b u t t u m$ meant a slave mark. The word abbuttum is written in $\S 1$ of Sumerian Family Laws, §§51-52 of Code of the Eshnunna, §146, 226-227 of the Code of Hammurabi, family law documents, grammatical texts, omen texts, and so on. What the abbuttum in Old-Babylonian period was has been discussed by many Assyriologists and scholars of cuneiform laws. It seems that their opinions are divided into the following three groups.

1) Haartracht theory (Landsberger)

2) Fessel-tag theory (Koschaker, Goetze)

3) tatoo theory (Driver-Miles, Szlechter)

On this problem, the clause of abbuttum gullubu has more important mean 
than that of abbuttam šakanu. gullubu means to shave. Therefore abbuttum was the thing which can be shaved. abbuttum was not a chain (tag), nor tatoo, but abbuttum-lock. The purpose of abbuttum worn by a slave was merely to confirm his master's ownership. abbuttum was not a mark to denote the severe distinction of classes.

\section{The geographer Isidoros of Charax and Mansiones Parthicae - Prolegomena of a study on Isidoros-}

Hozumi TaNaKa

Isidoros was an important geographer of Parthian Period, who was born in a Greek city called Charax Spasinu which was located at the mouth of the Tigris. His survived work "Mansiones Parthicae" is one of the very few records of the two great overland routes of the Parthian Empire, and it is also one of the most valuable materials for Parthian History since the works of the Parthian historians, that is, Apollodoros and other anonymous authors, have been lost.

However, the details of Isidoros' works and the era in which he lived in uncertain, so many scholars have studied them. For that reason, concerning my treatise I will investigate the proofs of scholars from the following points: 1) Isidoros' works of which there are at least three; The Geography of the World, The Description of Parthia, and Mansiones Parthicae. 2) The possible era in which his writing flourished; Isidoros' flourishing age was probably in the latter half of the first century A.D. and might be a little after Plinius the Elder. 3) Mansiones Parthicae in detail; above all, Mansiones Parthicae was an independent itinerary and it was written during the latter part of the Parthian Period, though his information was derived from an official survey of the Parthian Empire in the great period of Mithridates II (ca. 123-88/87 B.C.). 4) Comparison of the description of Parthia of Plinius' Naturalis Historia with Isidoros' Mansiones Parthicae. 